\title{
LEGACY ADMISSIONS
}

\section{A degree of uncertainty.}

\section{BY S. R. ALGERNON}

$\mathrm{M}$ $r$ Lindstrom shook my hand. It was a firm sixfingered grip. I could feel the bony nub where the seventh finger had been. Lindstrom looked around the empty banqueting hall and signed his name at the registration table by the door. The banner over his head read ALUMNI NETWORKING DINNER.

"Let me guess," I said. "Class of sixty-seven?"

"Sixty-three, actually."

His parents must have been early adopters. Maybe that explained the rebellious amputation. Fourteenfingered kids had been all the rage back in the Sixties, in homage to the keyboardist for The Rolling Beagles, a centenary tribute band to the British Invasion. That genetic tweak summed up - for me, at least - how our parents had got it all wrong. It wasn't their fault, though. What else could they have done, really?

"I'm glad you could make it," I said. "There are complimentary drinks at the bar, and the food will be ready soon. On your registration card, you listed 'Biometric consultant' as your occupation. That sounds exciting."

"Yeah," he said. He picked his name tag out from all the others and fidgeted with it. "I work for a bank. Transactions are automated now, so after a while the biometric scanner starts to forget what a real human looks like in the flesh. I help it to recalibrate its sensors. To tell you the truth, I think it's just lonely."

"Oh," I said. "If you aren't happy with your current job, we can help you find another. The university prides itself on a $100 \%$ employment rate for its graduates. That's a lifetime guarantee."

"I don't know yet. I think we need to get away from here and find someplace by the ocean, someplace with ... I don't know ... trees and everything, like it used to be."

He withdrew from our conversation as a memory flashed in his eyes with stark clarity.

"Eidetic?" I asked. He nodded. Photographic memories were all the rage, too, along with various learning and attention enhancements. The university recruited only the best applicants, with impeccable test scores and clear academic potential.

"Sorry. Is there anything I can do?"

"I don't think so," he said, with a hint of shame breaking through the nostalgia.

"Do you have any children?"

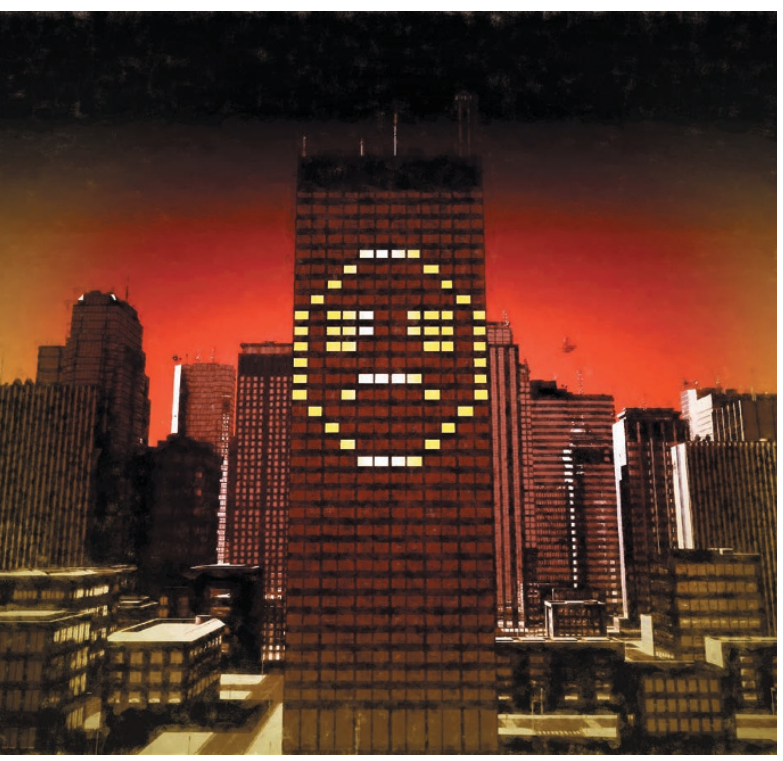

An empty self-driving shuttle van waited for me in the parking lot, the same one that had deposited me three hours earlier. It said nothing, and I was in no mood to break the silence.

I cut through the history department building on the way to the administration building. The cleaning bot whirred cheerfully as I walked past rows of offices. Each door was diligently locked, but if the university saw fit to let me inside, I was sure that I would find the offices in pristine condition, waiting for the next faculty hire.

"Good evening," I said to Professor Emeritus Franklin, through the open doorway to her office. She looked up from a paperback book and smiled at me as I passed.

Back at the administration build-

"Janice and Todd," he said, but without the pride that people used to have when they talked about such things.

"Don't worry," I said. "We have a legacy programme, you know. We'll have no problem getting them financial assistance, if they're keeping their test scores up."

"Not much point in that anymore."

"Well, is there any way I can help? It is my job after all."

"I don't know really," he said, glancing back at the doorway. "I guess I was just curious. I wanted to see if the place was still here, you know. I thought there might be people I could talk to."

"It's still early yet." I looked around at the circular banquet tables, each with six flawless place settings. The automated caterer rolled between them, with food trays in tow. "At least you could stay for the buffet."

"Sorry," he said. "I should be going. Still, it was nice meeting you."

"It was good of you to come. Please do remember our legacy programmes. The university is here for you."

"Thank you," he said, "I'll keep that in mind."

If I have to, was the unspoken addendum, if the ocean and the trees no longer sustain us.

$\mathrm{Mr}$ Lindstrom left. I was alone again, except for the machines that gathered up $\rightarrow$ NATURE.COM

Follow Futures: $\checkmark$ @NatureFutures f go.nature.com/mtoodm the food for reclamation promptly at nine.

At least someone showed up, I thought. Better than last year. ing, on the first floor, my office occupied the end of the hall. The sign on the door read OFFICE OF RECRUITMENT AND RETENTION. Its magnetic lock opened as I approached.

Once inside, I passed the empty cubicles and took a seat in the corner office. My three doctorates hung on the wall, along with the handful of master's degrees.

"University," I said, “could you add Todd and Janice Lindstrom to our list of potential recruits for ...?"

"2097 and 2099?"

"Yes, that's right," I sighed. "Is there anything else on my calendar for the week?"

"The next alumni event is in three months, twelve days. In the meantime, there are 2,793 online courses that you are qualified for, and as always you are entitled to a staff tuition waiver. Shall I enrol you in a course with one of our virtual professors?"

"Not tonight."

I cracked all twelve of my knuckles and swivelled my chair for a view of the vestigial skyline.

Were there people behind those windows, I wondered, or did the buildings leave the lights on to remind themselves how things used to be? I took some comfort in knowing that we humans weren't the only ones still caught up in the past.

S. R. Algernon studied fiction writing and biology, among other things, at the University of North Carolina at Chapel Hill. He currently lives in Singapore. 